\title{
Revisiting the probabilistic definition of drought: strengths, limitations and an agrometeorological adaptation
}

\author{
Gabriel Constantino Blain $\left(^{*}\right)$ \\ Instituto Agronômico, Centro de Ecofisiologia e Biofísica, Caixa Postal 28, 13012-970 Campinas (SP), Brasil. \\ (*) Corresponding author: gabriel@iac.sp.gov.br
}

Received: Nov. 29, 2011; Accepted: Feb. 2, 2012

\begin{abstract}
Drought is a slow-moving hazard that occurs in virtually all countries of the world. In the light of this, several indices have been developed to improve the detection of drought's onset, as well as quantifying other features of this phenomenon. The Standardized Precipitation Index (SPI) is often used in order to characterize meteorological droughts. In addition, this index is largely used by Brazilian's agricultural institutions. In order to add important information to the drought literature, this review article described a general definition of drought, evaluated it from a statistical point of view, and also described the SPI strengths and limitations. An adaptation of the SPI that aims to develop a probability-based agricultural drought index was also presented. The results obtained herein, associated with several studies carried out throughout the world, demonstrated that the SPI is not an agricultural index. It is just a mathematical approach developed to transforming skewed distributions into the Gaussian form. If this standardization cannot be achieved, the use of this index becomes meaningless. Therefore, a normality test should be used in establishing a temporal lower limit for the SPI computations. It was also verified that for periods in which the probability associated with the zero precipitation value is close to 0.5 , the SPI may erroneously indicate the end of an existing drought (or a decrease in its severity) in the presence of a decrease in the actual evapotranspiration values.
\end{abstract}

Key words: standardized precipitation index, normality, evapotranspiration.

\section{Revisão da definição probabilística de seca: qualidades, limitações e adaptação agrometeorológica}

\section{Resumo}

A seca é uma adversidade que se desenvolve lentamente ao longo do tempo, ocorrendo em praticamente todos os países do mundo. Consequentemente, diversos índices tem sido desenvolvidos para melhorar a detecção de seu início, bem como para quantificar demais características desse fenômeno. O Índice Padronizado de Precipitação (SPI) é frequentemente empregado na caracterização da seca meteorológica. Em adição, este índice é frequentemente utilizado por instituições agrícolas brasileiras. Objetivando adicionar relevantes informações à literatura relativa à referida adversidade, este trabalho descreveu uma definição geral de seca, avaliou a mesma sob o aspecto estatístico e ressaltou qualidades e limitações do SPI. Apresentou-se também uma adaptação desse modelo matemático que visa ao desenvolvimento de um índice probabilístico de seca agrícola. Os resultados, associados a diversos estudos desenvolvidos nas distintas regiões do Globo, demonstram que o SPI não é um índice de seca agrícola, sendo apenas uma abordagem matemática que visa transformar distribuições assimétricas para a forma Gaussiana. Uma vez que essa padronização não for atingida, o uso deste índice torna-se pouco consistente. Portanto, um teste de normalidade deve ser utilizado no estabelecimento de uma escala temporal mínima para seu cálculo. Verificou-se também que, em períodos em que a probabilidade associada ao valor zero de precipitação for próxima a 0,5, o SPI pode indicar uma melhora, ou até mesmo o fim das condições de um evento de seca mesmo existindo um déficit crescente de evapotranspiração real.

Palavras-chave: Índice Padronizado de Precipitação, normalidade, evapotranspiração. 


\section{INTRODUCTION}

The droughts events affect natural ecosystems as well as several human activities carried out throughout the world. In this last case, a prolonged and abnormally dry spell can severely impact from the subsistence farming systems to the most developed industrial activities. In fact, as many other natural hazards droughts events have plagued the civilization over the time (Негм JR., 2002). However, in comparison to other phenomena such as floods and earthquakes, the aforementioned hazard is perhaps the most difficult to define. As described in Wilhite (2000) the great number of sectors affected by drought, its temporal distribution, its geographical diversity, and the increasing demand placed on water supply by the man-made systems make it difficult to develop a single and universal definition of drought.

In order to overcome this difficulty, the scientific literature frequently recognizes three physical drought types: agricultural, meteorological and hydrological. As pointed out by Wilhite (2000) while a hydrological drought is associated with a deficiency in the volume of the water supply (e.g. reservoir storage), a meteorological drought can be seen as a result of a precipitation (PRE) shortage. An agricultural drought results from a shortage of available water for plant growth. Due to this lack of available soil moisture, the evapotranspiration losses are not properly replaced (WMO, 1975). The scientific literature also recognizes a fourth type of (non-physical) drought frequently referred to as a socioeconomic drought. As described in Keyantash and Dracup (2002), 'unless societal demand consistently exceeds natural supply, a socioeconomic drought will not occur without one or more of the other droughts'.

In spite of the existence of these different types of drought, there is a common feature associated with all of them. Already having been referred to as a 'creeping phenomenon' (GILlETE, 1950), drought is a slow-moving hazard that occurs in virtually all climatic regimes (HAYES et al., 2011). According to Mishra et al. (2007), the effects of a drought often accumulate slowly over a period of time. Consequently, the need of properly detecting the onset of a drought is a common goal for all drought monitoring systems (DMS). In the light of this, several indices have been developed to improve the detection of a drought's onset as well as quantifying other features of this creeping phenomenon, such as its intensity and duration. A review of drought indices developed during the twentieth century can be found in Heim JR. (2002). The reading of this important study is strongly recommended since 'knowing the history of drought index development helps take the confusion out of the complex issue of drought monitoring, drought impacts, and drought definitions' (Heim JR., 2002). Moreover, a critical step of nationals drought strategies should be the development (or the improvement) of comprehensive DMS capable of providing an early warning of drought's onset, as well as determining its spatial extent and severity. In addition, a DMS have to convey all these information to decisionmaking groups in a timely manner (HAYEs et al., 2011).

After all these considerations, the following recommendations, obtained from The Lincoln Declaration on Drought Indices ${ }^{(1)}$, may be highlighted: (1) 'The National Meteorological and Hydrological Services around the world are encouraged to use the Standardized Precipitation Index (SPI; McKee et al., 1993) to characterize meteorological droughts and provide this information on their websites, in addition to the indices currently in use. [...]. (2) A comprehensive user manual for the SPI should be developed that will provide a description of the index, the computation methods, specific examples of where it is currently being used, the strengths and limitations, mapping capabilities, and how it can be used'.

In Brazil, the SPI is largely used in operational mode by governmental agricultural institutions, such as Empresa Brasileira de Pesquisa Agropecuária (EMBRAPA), Instituto Agronômico (IAC) and, Instituto Nacional de Meteorologia (INMET). Thus, in order to add relevant information to the use of the SPI as well as to the drought literature, this review article is organized as follow: Section 2 describes a general definition of drought, evaluates it from a statistical point of view and also describes the SPI calculation algorithm highlighting its strengths. From the definition of agricultural drought, section 3 describes some limitations of the probabilistic approach inherent to the use of the SPI (especially those observed at short time scales). Section 4 describes an adaptation of the SPI that aims to develop a probability-based agricultural drought index capable of monitoring the deficits of actual evapotranspiration in a standardized way. General conclusions are given in section 5 .

\section{A GENERAL DEFINITION OF DROUGHT}

Considering the three types of physical drought, it becomes reasonable to accept that, 'generally defined, drought is a deficiency of precipitation relative to what is expected that, when extended over a season or a longer period of time, results in the inability to meet the demands of human activities and the

\footnotetext{
(1) This Inter-Regional Workshop was focused on developing standards for drought indices and guidelines for drought early warning systems (HaYes et al., 2011). The reader is referred to www.wmo.int/pages/prog/wcp/agm/meetings/wies09/documents/Lincoln_Declaration_Drought_Indices.pdf, for further information.
} 
environment' (Hayes et al., 2011). From a statistical point of view, the expression 'what is expected' can be understood as being the precipitation amounts, accumulated over a particular period of time, associated with cumulative probabilities close to the 0.5 value. Consequently, the expression 'deficiency of precipitation' may be described by cumulative probabilities lower than this median value.

After McKee et al. (1993) we may indicate that the time scale over which this deficiency of precipitation accumulates is extremely important and functionally separates different types of (physical) drought. Moreover, also according to McKeE et al. (1993), we may accept that if the precipitation data could be seen as coming from a normal distribution, the difference between an observed precipitation amount $\left(\mathrm{P}_{\mathrm{t}}\right)$ and its mean historical value $\left(\mathrm{P}_{\mathrm{i}}\right)$, divided by its standard deviation $\left[\mathrm{SD}_{\mathrm{i}} ; \mathrm{DI}_{\mathrm{i}}=\left(\mathrm{P}_{\mathrm{t}}-\mathrm{P}_{\mathrm{i}}\right) / \mathrm{SD}_{\mathrm{i}}\right]$ would be taken as a standardized drought indicator. By varying the time scale associated with DI calculations, we would be (functionally) addressing different types of physical droughts. From this hypothetical assumption, DI would be taken as a temporally and spatially invariant drought index. Since each DI value would have been obtained from a normal distribution, a particular DI value would always be associated with the same rarity of a given deficiency of precipitation occurred in any region, during any period, and accumulated over any time scale. However, it is well known that precipitation is usually not normally distributed. Furthermore, the parameters of such zero-bounded distributions vary widely among different areas and among different periods (Figure 1). Therefore, DI cannot be taken as a temporally/spatially invariant drought index. A particular DI value is not easily comparable among different regions and among different periods.

In spite of the great variability of the precipitation distributions over the time-space domain, the SPI was designed to be a spatially/temporally invariant drought indicator capable of representing drought

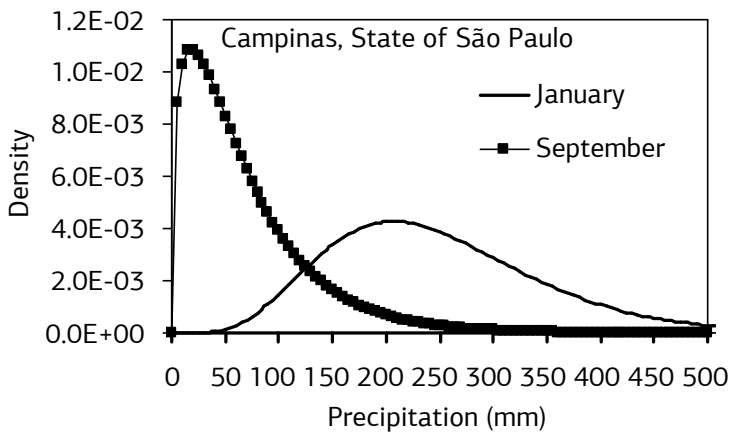

and flood events in a similar probabilistic way, even when different precipitations regimes are being evaluated (Wu et al., 2007). As described in Guttman (1998) the SPI calculation stars by determining a probability density function (pdf) capable of properly describing the long-term observed precipitation. Although the gamma 2-parameter distribution (Gam) is frequently employed, Guttman (1999) indicates that the Pearson type III distribution (PE3; a 3 -parameter function) is the best universal model for SPI calculations. Kumar et al. (2009) also suggested that the PE3 distribution may be a better choice than the Gam distribution, on SPI calculations. By using monthly precipitation data of Mexico, Sото et al. (2005) concluded that the differences between SPI final values, obtained from both PE3 and Gam, were non significant and averaged zero. According to Wu et al. (2007) the Gam distribution can affect the confidence in the SPI results, because its pdf has (only) two free parameters, which would not give the best goodness-of-fit for a given (precipitation) series. Also according to Wu et al. (2007), other alternative distributions, such as PE3, are worth to be studied. BLAIN (2011a) recommends the use of the PE3 in the SPI calculation algorithm in the State of Sáo Paulo, Brazil. ZANG et al. (2009) used the lognormal distribution in the SPI calculation algorithm in the Pearl River Basin, China.

Once a pdf is chosen, the cumulative probability $[\mathrm{H}(\mathrm{PRE})]$, associated with a given precipitation amount, are obtained from the cumulative density function $c d f(x)=\int_{0}^{x} p d f(t) d t$ (the lower limit is due to the fact that the precipitation distributions are zero-bounded). $\mathrm{H}(\mathrm{PRE})$ is then estimated from the following mixed distribution: $H(P R E)=(m / N)+[1-(m / N)] c d f(x)$, where $\mathrm{m}$ is the number of zeros in a dataset composed by $\mathrm{N}$ observations. As described in Wu et al. (2007) the final step of this equiprobability transformation are based on the following rational approach (ABramowitz and STEGUN, 1965).

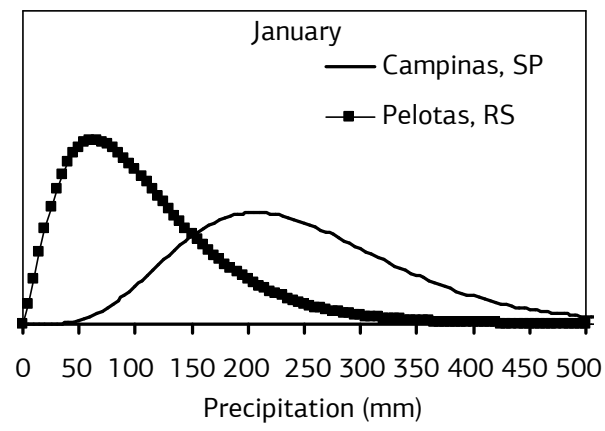

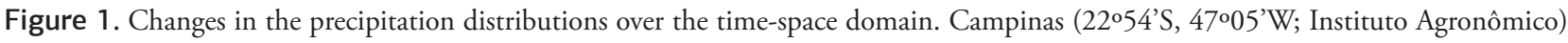
and Pelotas (31 $45^{\prime}$ S, 52²1'W; Universidade Federal de Pelotas). 
$S P I=-\left(t-\frac{c_{0}+c_{1} t+c_{2} t^{2}}{1+d_{1} t+d_{2} t^{2}+d_{3} t^{3}}\right)$ when $0<\mathrm{H}(\mathrm{PRE}) \leq 0.5$
$S P I=+\left(t-\frac{c_{0}+c_{1} t+c_{2} t^{2}}{1+d_{1} t+d_{2} t^{2}+d_{3} t^{3}}\right)$ when $0.5<\mathrm{H}(\mathrm{PRE})<1$

$t=\sqrt{\left(\ln \left(\frac{1}{(H(P R E))^{2}}\right)\right.}$ when $0<\mathrm{H}(\mathrm{PRE}) \leq 0.5$

$t=\sqrt{\left(\ln \left(\frac{1}{(1-H(P R E))^{2}}\right)\right.}$ when $0.5<\mathrm{H}(\mathrm{PRE})<1$

$$
\begin{aligned}
& c_{0}=2.515517 \\
& c_{1}=0.802853 \\
& c_{2}=0.010328
\end{aligned}
$$$$
d_{2}=0.189269
$$$$
d_{3}=0.001308
$$

A drought event starts when the SPI first fall below zero and ends when a positive value follows a value of SPI $\leq-1$ (Table 1). As can be noted from equations 1 and 2 , the SPI is essentially an equiprobability transformation

Table 1. Standardized Precipitation Index (SPI) values and the associated drought categories (MCKEE et al., 1993)

\begin{tabular}{|cc|}
\hline SPI values & Drought Category \\
\hline 0 to -0.99 & mild drought \\
-1.00 to -1.49 & moderate drought \\
-1.50 to -1.99 & severe drought \\
$\leq-2.00$ & extreme drought \\
\hline
\end{tabular}

of the precipitation distributions (WU et al., 2007). Therefore, conceptually, a particular value of this drought index will always be associated with a particular H(PRE) no matter where or when it was obtained (Figure 2). Consequently, based on the general definition of drought, described at the beginning of this section, and assuming that the equiprobability transformation of the precipitation distribution was (really) achieved, a particular negative SPI value will represent a particular severity of drought no matter where or when this natural hazard is being monitored. Thus, in spite of the fact that the precipitation distributions vary widely over the time-space domain, the SPI is easily comparable among different regions and among different periods.

As described in HAYEs et al. (1999), from this normality assumption, a SPI value of less than -3.0 will occur once in 200 years; values of less than -2.0 will occur two to three times in 100 years and values less than -1.0 will occur 16 times in 100 years. It is also worth emphasizing that the equiprobability transformation also allows the SPI to determine the precipitation amount, as well as its probability of occurrence, required to end a drought event. As can be noted, the SPI assumes that the droughts events occur with the same frequency for any location in which the normality assumption is met. Thus, the SPI was not designed for identify regions that are more 'droughtprone' than others (HAYEs et al., 1999).

After all these considerations, associated with the equiprobability transformation of the precipitation distributions, it becomes worth mentioning that according to Wu et al. (2007) the SPI is now widely accepted
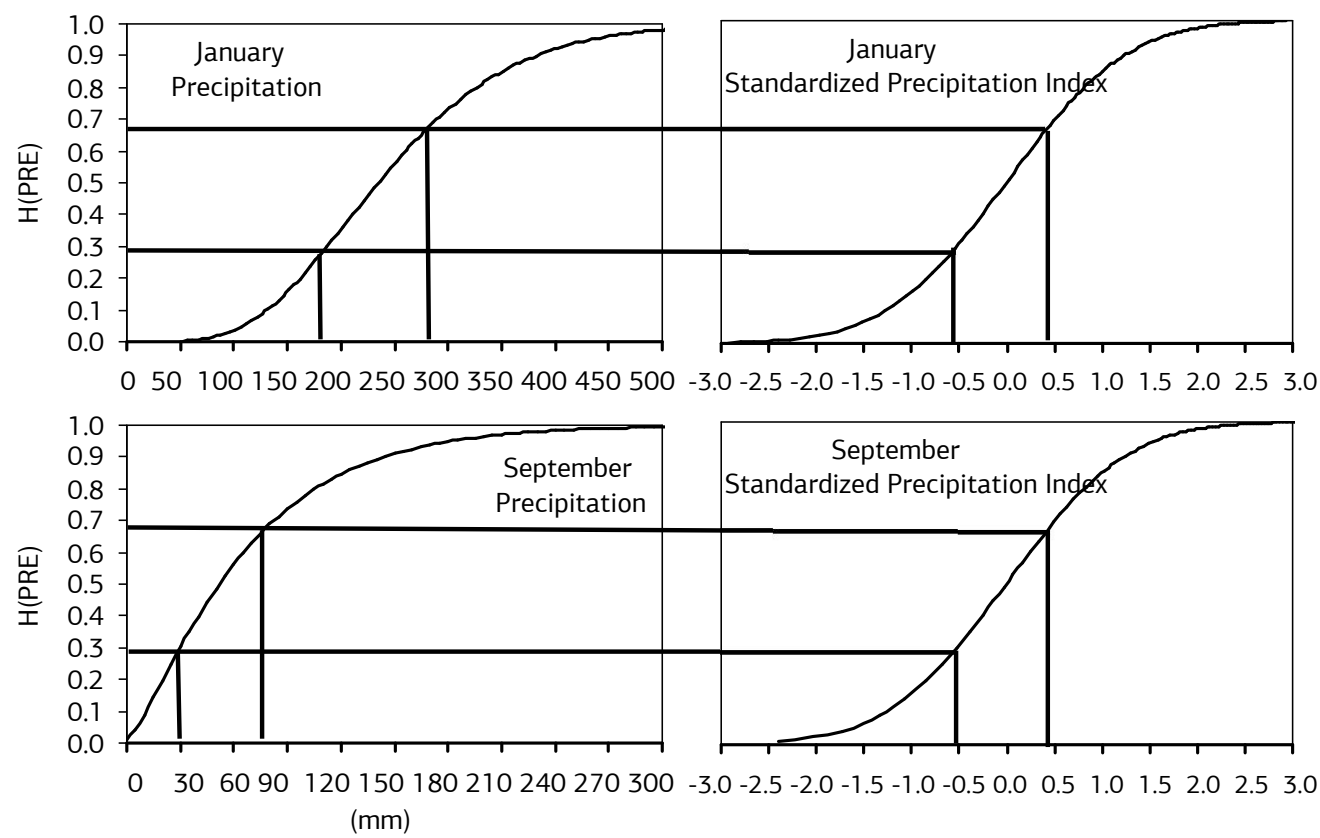

Figure 2. Equiprobability transformation of precipitation amounts obtained from the weather station of Campinas $\left(22^{\circ} 54^{\prime} \mathrm{S}\right.$, $47^{\circ} 05^{\prime} \mathrm{W}$; Instituto Agronômico). 
throughout the world in both operational and research modes because it is, conceptually, normalized to a location and is normalized in time. For instance, HAYEs et al. (1999) evaluated the performance of the SPI in monitoring the 1996 drought in the Southern plains and southwestern United States. Based on SPI time series, Mishra and Desai (2005) developed mathematical models in order to forecast droughts in Kansabati River basin, India. Mishra et al. (2007) employed the SPI to evaluate the transition probabilities of drought events also in the Kansabati River basin. Livida and Assemakopoulos (2007) used this drought index to evaluate several features of the drought events detected in Greece (1951 to 2000). After have applied the SPI in Nebraska, USA, TADESSE et al. (2005) indicated that most occurrences of drought events (1950 to 1999) was preceded, among others oceanic-atmospheric parameters, by positive values of the Southern Oscillation Index (SOI; related to the El Niño/southern oscillation). By using the SPI calculated at several time scales throughout the Europe (1901-2000), LóPEZ-MORENO and ViCENTE-SERRANO (2007), evaluated the 'responses of droughts' to the positive and negative phases of the Wintertime North Atlantic Oscillation. MANATSA et al. (2010) used the SPI to address several features of agricultural droughts in Zimbabwe, Africa. In order to evaluate the ability of the SPI for estimating the upland rice yield in the location of Goiâna (State of Goiás, Brazil), Fernandes et al. (2010) addressed important limitations of the use of the SPI as an agricultural drought indicator. KHAN et al. (2008) used the SPI to track droughts and assess the impacts of precipitation variability on shallow groundwater in Murray-Darling Basin, Australia. According to these authors, the SPI can successfully capture dry as well as wet periods and also can identify historical droughts over the century scale. According to Blain and Kayano (2011), the standardized treatment of the precipitation amounts achieved through the SPI calculation algorithm makes it an interesting alternative in investigating the conditioning/modulating climatic forcing of a given region. Indeed, considering the results obtained from the global wavelet power spectrum (GWP; Figure 3), a variance peak above the 5\% significance level (4-yr band) is observed only for the SPI signal. No significant variance peak is observed in the GWP of the precipitation signal.

Given that the SPI requires only precipitation data for its calculation, the difference between figure $3 \mathrm{a}, \mathrm{b}$ seems to be a consequence of the fact that a particular SPI value represents the same climatic condition (concerning drought as well as flood events) no matter the month from which it was obtained. However, as previously discussed (Figure 1), there is no guaranty that a particular value of the residual precipitation represents (from a statistical point of view) the same climatic condition when it is obtained from different months or locations. At this point, it is worth highlighting a statistical consideration extracted from Grinsted et al. (2004): 'Our experience with continuous wavelet transforms of geophysical time series shows that series far from normally distributed produces rather unreliable and less significant results'. Consequently, we may assume that the equiprobability transformation of the precipitation distributions may be a very helpful step in climate variability investigations.

The SPI has also been used on scientific studies focused on the detection of climate trends. Based on the SPI, ZHANG et al. (2009) observed changes in the events of drought and wetness in Pearl River Basin; China (1960-2005). Zhai et al. (2010) demonstrated that the SPI can be used to describe possible trends in the dryness and wetness conditions in the regions of China, as well as in other countries. Li et al. (2008) observed that the values of the SPI computed over southern Amazon region decreased in the period of 1970 to 1999 by 0.32 per decade. According to these authors this result indicates an increase trend in dryness conditions. It is worth mentioning that a natural consequence of the aforementioned equiprobability transformation is the removal of the seasonality usually observed in meteorological data. Consequently, at least conceptually, trend analyses applied to SPI time series are not affected by the presence of this aforementioned component. However, concerning climate change studies, Dubrovsky et al. (2008) concluded that the Palmer Drought Severity Index (PALmer, 1965) is more suited than the SPI for assessing the potential impacts of the Global Warming on future droughts. A similar indication can be found in BRÁzDIL et al. (2009). After have evaluated the variability of droughts observed in Czech Republic from 1881 to 2006, they assumed that the SPI is not suited for evaluating long-term drought trend, because it is based only in precipitation data. (a) Residual Precipitation

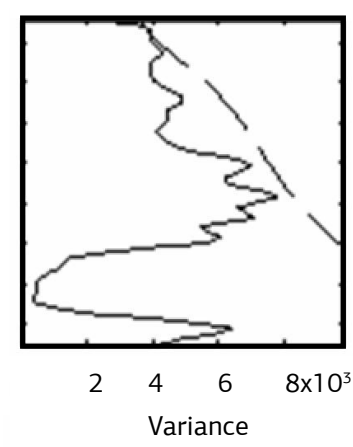

(b) 1-Month SPI

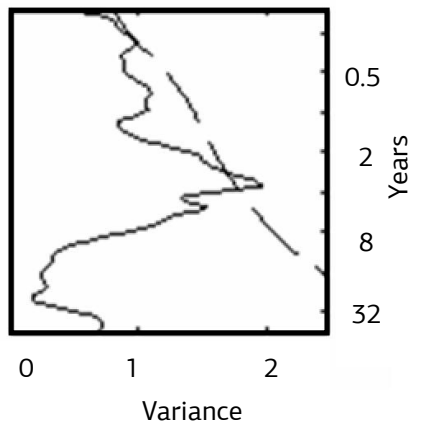

Figure 3. Wavelet power spectrum (in variance units). Campinas, (22054'S, 4705'W; Instituto Agronômico). The corresponding medians of each monthly precipitation value were removed. The wavelet analysis was carried out by following TORRENCE and Сомро (1998). 
From the definition of agricultural drought, presented in section 1, it becomes clear that the soil moisture (or parameters related to it) is a key variable for the evaluation of this type of drought. After Sims et al. (2002) have studied the use of the SPI for estimating soil moisture, they indicated that this drought index appears to be suited for estimating soil moisture deficit. However, these authors also indicated that the SPI gives some erroneous spikes when it is calculated at short time scales. According to Sims et al. (2002) this suggests that there can be a temporal lower limit for the derivation of a meaningful relationship between the SPI and soil moisture parameters. Indeed, as will be shown in section 3, it seems that there is a temporal lower limit for the calculation of meaningful SPI values.

\section{LIMITATIONS}

After GutTman (1994) has investigated the effect of the length of the data records on precipitation distributions, he stated that at least 40-60 years are required for parameter estimation stability in the central part of the distributions. Furthermore, GutTMan (1994) also stated that about 70-80 years of records are required for achieving the stability in the tails of the precipitation distributions. Since an extreme drought is a rare event, the tails of the precipitation distributions are extremely important in the use of the SPI (Wu et al., 2005). Consequently, the ideal length of precipitation records required for the SPI calculation cannot be met in several parts of the world. In addition, Wu et al. (2005) stated that inconsistent results may be obtained when different time lengths of data records are used in the calculation of the SPI. Nevertheless, these inconsistent results are observed only in the presence of a temporal change in parameters of the pdf used for describing the precipitation series (Wu et al., 2005).
This last feature can be algebraically evaluated from a particular precipitation total $(10 \mathrm{~mm})$ and by considering the results obtained from the study of BLAIN et al. (2009), which show a significant temporal change in the parameters of the gamma distribution ( $\alpha$ and $\beta$ ) during the months of May in the location of Campinas, State of São Paulo. In this case, it can be observed remarkable changes in the SPI values when different time spans are used in its calculation: $1890-2006, \alpha=1.3, \beta=46.9, \mathrm{SPI}_{(10 \mathrm{~mm})}=-1.27 ; 1890-1928$, $\alpha=1.18, \beta=44.45$, SPI $_{(10 \mathrm{~mm})}=-1.08 ; 1929-1967, \alpha=1.3$, $\beta=46.9, \mathrm{SPI}_{(10 \mathrm{~mm})}=-0.80 ; 1968-2006, \alpha=1.64, \beta=45.07$, $S P I_{(10 \mathrm{~mm})}=-1.64$. It is worth emphasizing that considering the period of 1929-1967 the SPI ${ }_{(10 \mathrm{~mm})}$ has indicated a near normal condition (table 1). However, for the period of 1968-2006, the SPI $I_{(10 \mathrm{~mm})}$ has indicated severely dry conditions. Consequently, 'the SPI user should be aware that inconsistent conclusions could be obtained if different time lengths of precipitation record are involved in the SPI calculation' (Wu et al., 2005). Therefore, by following these last authors, it is recommended that a DMS adopt a common period of records for calculating the SPI among different locations. The aforementioned time span should be as long as possible.

Considering the information presented in section 2, we may infer that being normally distributed is the basic feature of the SPI. In the light of this, an important limitation of its use comes from the definition of drought adopted by this probability-based index. As can be easily verified from its calculation algorithm, the SPI indicates the presence of a drought only if the observed precipitation amount is associated with $\mathrm{H}(\mathrm{PRE})<0.5$. Although this feature is consistent with the idea that a drought event is triggered by a deficiency of precipitation; in regions (or periods) in which the zero precipitation value is climatologically expected $[\mathrm{H}(\mathrm{PRE}=0) \approx 0.5]$, the SPI might not be capable of assuming negative values. In other words, the SPI will ever be able to indicate a drought condition. In

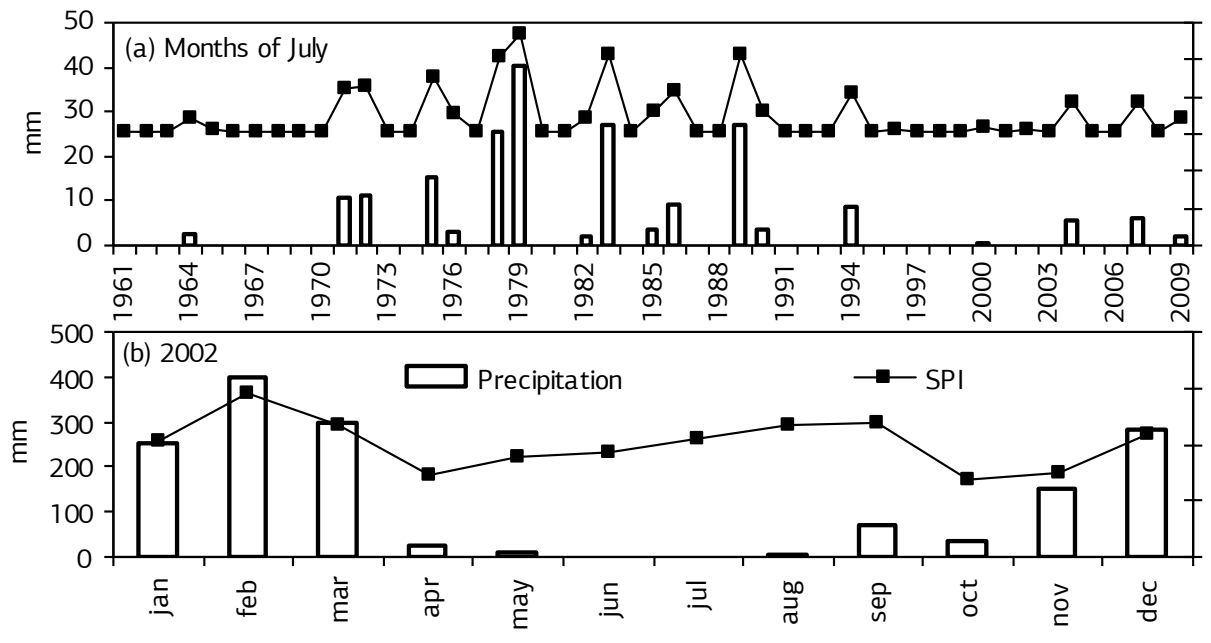

Figure 4. Temporal variability of the Standardized Precipitation Index (SPI). Goiânia, (16 43’S, 49²0’W; Instituto Nacional de Meteorologia). 
order to evaluate this last statement, Figure 4 depicts the SPI calculated for the Months of July (1961-2009) and the SPI values obtained during 2002 from the weather station of Goiânia-Go, Brazil.

After analyzing figure $4 \mathrm{a}$ it becomes worth mentioning that the frequency of occurrence of $\mathrm{PRE}=0$ for the Months of July in the location of Goiânia is approximately 57\%. Consequently, the minimum possible value of $\mathrm{H}(\mathrm{PRE})$ will always be greater than 0.5 . Thus, no negative value will be obtained from equations 1 and 2. Under these circumstances, commonly observed in locations with a distinct dry season, the SPI (especially at short time scales) fails to evaluate a drought condition (WU et al., 2007). Under this high frequency of $P R E=0$, the equiprobability transformation of the precipitation distributions might not be achieved. The SPI will not be normally distributed. Consequently, under these circumstances, there is no guaranty that the SPI is indeed an invariant drought indicator capable of representing precipitations deficits/excess, obtained from different precipitations regimes, in a similar probabilistic way. At this point, we strongly recommend the reading of the great study of $\mathrm{Wu}$ et al. (2007), that aims to reveal the effects of arid climates and dry seasons on SPI values. These authors used a normality test to investigate whether the values of this drought index, obtained from several locations, are capable of representing dry and wet periods in a similar (invariant) way. This test is described as follow: 'A (SPI) distribution is considered nonnormal when its variables related to the distribution meet three criteria simultaneously: (1) Shapiro-Wilk statistic, W, less than 0.96 ; (2) p-values less than 0.10 ; and (3) the absolute value of the median greater than 0.05 . Otherwise, the distribution is normal' (Wu et al., 2007).

Finally, it is well known that the monitoring of an agricultural drought needs to be carried out at short time scales (Heim JR., 2002), since the temporal distribution of the precipitations events within a year or even within a month is one of the key factors for several agricultural activities (Ramos and Casasnovas-Martínes, 2006; Blain and Brunini, 2007a; and Blain, 2011b). However, a short time scale increases the precipitation variability (Wu et al., 2007) as well as the probability associated with PRE $=0$. Therefore, 'the SPI may fail to properly detect a shortage of available water for plant growth' (BLAIN, 2011c).

\section{PROBABILITY-BASED AGRICULTURAL DROUGHT INDEX}

In order to develop a probability-based agricultural drought index, BLAIN and Brunini (2007b) adapted the SPI calculation algorithm to evaluate ten-day values of actual evapotranspiration (AE). This adaptation was called as the Standardized Actual Evapotranspiration Index (IPER) and was carried out under the climate conditions of the State of São Paulo. Similar to the SPI, the IPER calculation starts by determining a probability density function (pdf) capable of properly describing the long-term observed EA data. Once a pdf is chosen, the $\mathrm{H}(\mathrm{EA})$ values are obtained from the cumulative density function [cdf(EA)]. The inverse normal function (Equations 1 and 2) is then applied to $\mathrm{H}(\mathrm{EA})$, resulting in the IPER. Although BLAIN and BRUNinI (2007b) have recommended the use of the 2-parameter beta distribution in the IPER calculations, we decided to use the general extreme value distribution (GEV). Based on EA series (1970-2010) obtained from the locations of Campinas

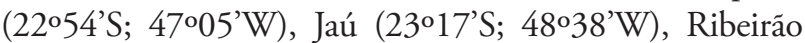

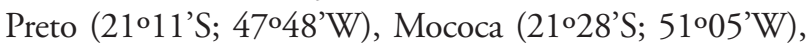

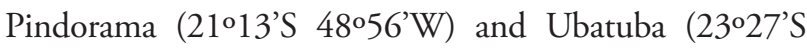
$\left.45^{\circ} 04^{\prime} \mathrm{W}\right)$ and by considering soil water availability equal to 50,100 and $150 \mathrm{~mm}$, it was verified that in comparison to other distributions, such as gamma 2-parameters, lognormal, normal and beta, this 3-parameter function was the only one capable of providing normally distributed IPER datasets for each one of the 36 ten-day periods (in all locations). The normally assumption was evaluated by following Wu et al., (2007). Since the parameters of the GEV were estimated using all available data, the KolmogorovSmirnov/Lilliefors test (KS-L) were used to verify the fit of the EA datasets to the aforementioned parametric distribution (Steinskog et al., 2007; Vlcek and Huth, 2009). The statistical simulations required for calculating the KS-L test were based on the procedure called "non-uniform random number generation by inversion". It were generated 100000 synthetic data samples for each ten-day period. The KS-L has indicated that the GEV distribution can be used to describe the probability structure of the EA series. More information about the KS-L can be found in WILKS (2006). Given that the equiprobability transformation of the EA distributions was achieved, we may assume that a particular negative IPER value will represent a particular severity of EA deficit for any one of these six locations on any ten-day period of the year.

Before analyzing figure 5 it is worth mentioning that during the Winter Months the location of Campinas presents strongly skewed precipitation distributions, in which a PRE $=0$, at a ten-day scale, is highly expected. For instance, the frequency of occurrence of PRE $=0$ obtained during the $2^{\text {nd }}$ ten days of the Month of August (19482010; the apex of the local dry season) is approximately 55\%. As can be seen in Figure 5a the SPI values increase from the $1^{\text {st }}$ ten days of June to the $1^{\text {st }}$ ten days of July even though no precipitation has been observed. This increase of the SPI is due to the increase of $\mathrm{H}(\mathrm{PRE}=0)$ as we get closer to the apex of the dry season. Evidently, this unreal change to wetter conditions in the presence of no precipitation event is physically inconsistent and also indicates that the SPI may fail to properly track an agricultural drought. As can be noted (Figure 5b), there is, in fact, a decrease in both EA and IPER from the $1^{\text {st }}$ ten days of May to the $1^{\text {st }}$ ten days of July. 

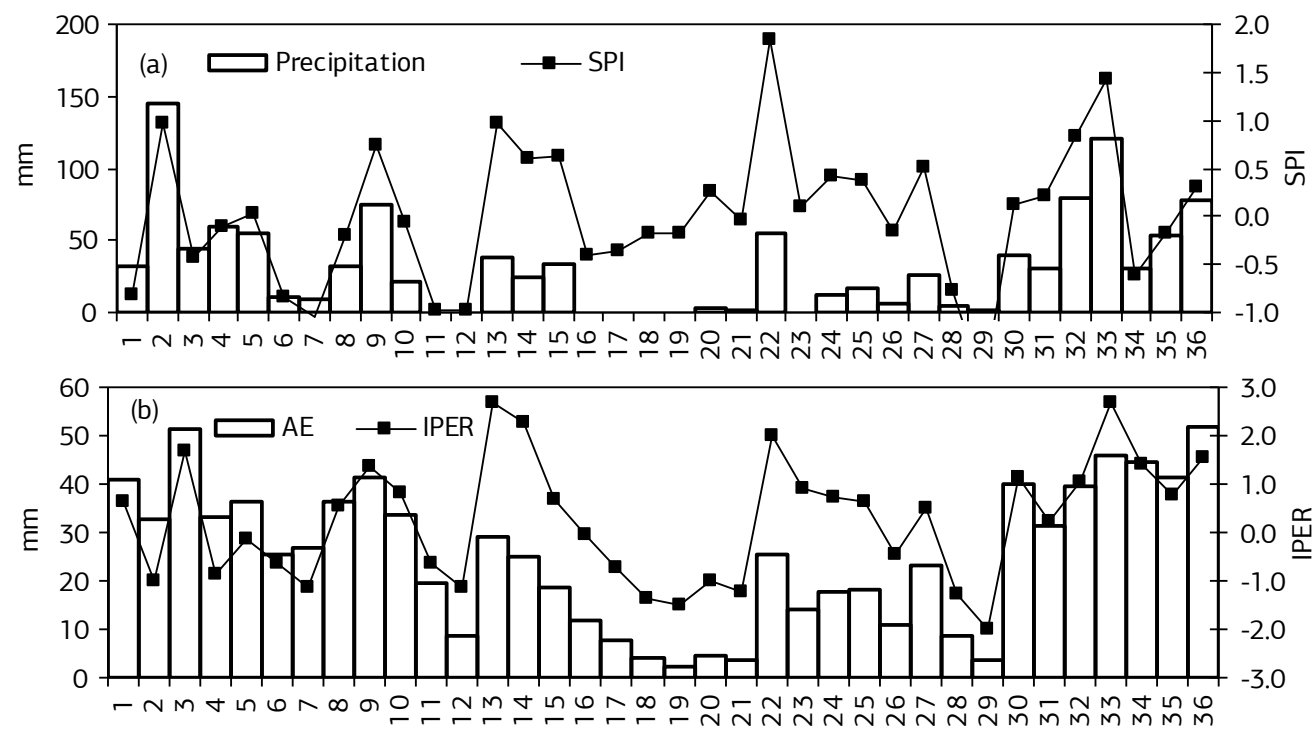

Figure 5. Precipitation totals, Standardized Precipitation Index (SPI), actual evapotranspiration (AE) and Standardized Actual Evapotranspiration Index (IPER) observed during each one of the 36 ten-day periods of 2002 . Campinas (22 $54^{\prime} \mathrm{S}$, 47º $05^{\prime} \mathrm{W}$; Instituto Agronômico).

Given that Blain and Pires (2011) described the presence of temporal persistence in ten-day EA series, it becomes worth emphasizing that a parametric summarization of a dataset, in which the presence of serial correlations cannot be neglected, may result in loss of information (MaIA et al., 2007). Even though the aforementioned cdf summary is used only as a step for achieving the equiprobability transformation of the EA distributions (in which the time span between two subsequent values is one year), further investigations are required for verifying the effect of this component in the IPER values. It also has to be emphasized that the KS-L test is only appropriated for evaluating the central part of the distributions (SAnsigolo, 2008). However, as described at the beginning of this section, special focus should be given for the lower tail of the distributions. Thus, further investigations are still required in order to verify the confidence of the IPER values obtained from the GEV function (other pdf are worthy to be evaluated). In other words, further studies are required for establishing a standard IPER calculation algorithm. It is also recommended that future studies evaluate the possibility of employing a crop coefficient in the IPER calculation algorithm.

\section{CONCLUDING REMARKS}

In spite of its use in agricultural institutions, the SPI is not an agricultural drought index. It is just a mathematical approach developed to transforming skewed precipitation distributions into the Gaussian form. If this equiprobability transformation cannot be achieved, the use of this standardized drought index becomes meaningless. As demonstrated herein, choosing an appropriate temporal lower limit is a critical step for the calculation of this probability-based model and, consequently, for achieving the normality assumption inherent to its use. Therefore, I strongly recommend that the operational use of this drought index, especially those carried out by agronomic institutions, should be preceded by a normality test. The results obtained from this test should be used for establishing the temporal lower limit required for the calculation of meaningful SPI values.

It was demonstrated that for periods in which the cumulative probability associated with the zero precipitation value is close to or greater than 0.5 , the SPI may indicate the end of an existing drought (or a decrease in its severity) in the presence of no precipitation. Under this circumstance, it was verified an increase in the SPI values in the presence of a decrease in the actual evapotranspiration values.

\section{REFERENCES}

ABRAMOWITZ, M.; STEGUN., I.A. Handbook of mathematical function, Dover: Editora, 1965, 1046p.

BLAIN, G.C.; BRUNINI, O. Análise da escala temporal de monitoramento das secas agrícolas e meteorológicas no Estado de São Paulo, Revista Brasileira de Meteorologia, v.22, p.255-261, 2007a.

BLAIN, G.C.; BRUNINI, O. Quantificação da seca agrícola pelo índice padronizado de evapotranspiração real (IPER) no estado de São Paulo, Bragantia, v.65, p.517-525, 2007 b. 
BLAIN, G.C.; KAYANO, M.T. 118 anos de dados mensais do Índice Padronizado de Precipitação: série meteorológica de Campinas, Estado de São Paulo, Revista Brasileira de Meteorologia, v.26, p.137-149, 2011.

BLAIN, G.C.; KAYANO, M.T.; CAMARGO, M.B.P.; LULU, J. Variabilidade amostral das séries mensais de precipitação pluvial em duas regióes do Brasil: Pelotas-RS e Campinas-SP. Revista Brasileira de Meteorologia, v.24, p.1-11, 2009.

BLAIN, G.C. Standardized precipitation index based on pearson type III distribution. Revista Brasileira de Meteorologia, v.26, p.167-180, 2011a.

BLAIN, G.C. Totais decendiais de precipitação pluvial em Campinas, SP: persistência temporal, periodicidades e tendências climáticas, Ciência Rural, v.41, p.789-795, 2011 b.

BLAIN, G.C. Aplicação do conceito do índice padronizado de precipitação à série decendial da diferença entre precipitação pluvial e evapotranspiração potencial, Bragantia, v.70, p.234-245, 2011c.

BLAIN, G.C.; PIRES, R.C.M. Variabilidade temporal da evapotranspiração real e da razão entre evapotranspiração real e potencial em Campinas, Estado de São Paulo, Bragantia, v.70, p.460-470, 2011.

BRÁZDIL, R.; TRNKA, M.; DOBROVOLNÝ, P.; CHROMÁ, K.; HLAVINKA, P.; ŽALUD, Z. Variability of droughts in the Czech Republic, 1881-2006, Theoretical and Applied Climatology, v.99, p.297-315, 2009.

DUBROVSKY, M.; SVOBODA, M.D.; TRNKA, M.; HAYES, M. J.; WILHITE, D. A.; ZALUD, Z.; HLAVINKA, P. Application of relative drought indices in assessing climate-change impacts on drought conditions in Czechia, Theoretical and Applied Climatology, v.96, p.155-171, 2009.

FERNANDES, D.S.; HEINEMANN, A.B.; PAZ, R.L.F.; AMORIM, A.O. Desempenho de índices quantitativos de seca na estimativa da produtividade de arroz de terras altas. Pesquisa Agropecuária Brasileira, v.45, p.771-779, 2010.

GILLETTE, H.P. A creeping drought under way. Water and Sewage Works, p. 104-105, 1950.

GRINSTED, A.; MOORE, J.C.; JEVREJEVA, S. Application of the cross wavelet transform and wavelet coherence to geophysical time series. Nonlinear Processes in Geophysics, v.11, p.561-566, 2004.

GUTTMAN, N.B. On the sensitivity of sample L moments to sample size. Journal of Climatology, v.34, p.113-121, 1994.

GUTTMAN, G.B. Comparing the Palmer Drought Index and the "Standardized Precipitation Index". Journal of the American Water Resources, v.16, p.113-121, 1998.

GUTTMAN, G.B. Accepting the "Standardized Precipitation Index": a calculation algorithm index. Journal of the American Water Resources, v.35, p.311-322, 1999.

HAYES, M.J.; SVOBODA, M.D.; WILHITE, D.A.; VANYARKHO, O.V. Monitoring the 1996 drought using the Standardized Precipitation Index. Bulletin of the American Meteorological Society, v.80, p.429-438, 1999.

HAYES, M.J.; SVOBODA, M.D.; WALL, N.; WIDHALM, M. The Lincoln Declaration on Drought Indices - Universal meteorological drought index recommended, Bulletin of the American Meteorological Society, v.92, p.485-488, 2011.

HEIM Jr., R.R. A review of twentieth - century drought indices used in the United States. Bulletin of the American Meteorological Society, v.83, p.1149-1163, 2002.

KHAN, S.; GABRIEL, H.F.; RANA, T. Standard precipitation index to track drought and assess impact of rainfall on watertables in irrigation areas. Irrigation Drainage Systems, v.22, p.159-177, 2008 .

KEYANTASH, J.; DRACUP, J.A. The quantification of drought: An evaluation of drought indices. Bulletin of the American Meteorological Society, v. 83, p.1167-1180, 2002.

KUMAR, M.N.; MUTHLY, C.S.; SAI, M.V.R.S.; ROY, P.S. On the use of Standardized Precipitation Index (SPI) for drought intensity assessment. Meteorological Applications, v.16, p.381-389, 2009.

LI, W.; FU, R.; JUAREZ, R.I.N.; FERNANDES, K. Observed change of the standardized precipitation index, its potential cause and implications to future climate change in the Amazon region. Philosophical Transactions of the Royal Society, v. 363, p.17671772, 2008.

LIVIDA, I.; ASSEMAKOPOULOS, V.D.; Spatial and temporal analysis of drought in Greece using the Standardized Precipitation Index (SPI). Theoretical and Applied Climatology, v.89, p.143153, 2007.

LÓPEZ-MORENO, J.I.; VICENTE-SERRANO, S.M. Positive and negative phases of the wintertime North Atlantic Oscillation and drought occurrence over Europe: A multitemporal-scale approach. Journal of Climate, v.21, p.1220-1242, 2008.

MAIA, A.H.N.; MEINKE, H.; LENNOX, S.; STONE, R.C. Inferential, non-parametric statistics to assess quality of probabilistic forecast systems. Monthly Weather Review, v.135, p.351-362, 2007.

MANATSA, D.; MUKWADA, G.; SIZIBA, E.; CHINYANGANYA, T. Analysis of multidimensional aspects of agricultural droughts in Zimbabwe using the Standardized Precipitation Index (SPI). Theoretical and Applied Climatology, v.102, p.287-305, 2010.

MCKEE, T.B.; DOESKEN, N.J.; KLEIST, J. The relationship of drought frequency and duration to the time scales. In: CONFERENCE ON APPLIED CLIMATOLOGY, 8., 1993, Anaheim. Proceedings. Boston: American Meteorological Society, 1993. p.179-184.

MISHRA, A.K.; DESAI, V.R. Drought forecasting using stochastic models, Stochastic Environmental Research Risk Assessment, v.19, p.326-339, 2005.

MISHRA, A.K.; SINGH, V.P.; DESAI, V.R. Drought characterization: a probabilistic approach. Stochastic Environmental Research Risk Assessment, v.23, p.41-55, 2007. 
PALMER, W.C. Meteorological drought. Washington: U.S. Department of Commerce, 1965. 58p. (U.S. Department of Commerce. Research paper, 45)

RAMOS, M.C.; CASASNOVAS-MARTÍNES, J.A. Trends in Precipitation Concentration and Extremes in the Mediterranean Penedès-Anoia Region, Ne Spain. Climate Change, v.74, p.457474, 2006.

SANSIGOLO, C.A. Distribuiçóes de extremos de precipitação diária, temperatura máxima e mínima e velocidade do vento em Piracicaba, SP (1917-2006). Revista Brasileira de Meteorologia, v.23, p.341-346, 2008.

SIMS, A.P.; NIYOGI, D.; RAMAN, S. Adopting drought indices for estimating soil moisture: A North Carolina case study. Geophysical Research Letters, v.29, p.24.1-24.4, 2002.

SOTO, L.G.M.; RUTHERFORD, B.M.; MAAROUF, A Standardized Precipitation Index Zones for México. Atmosfera, v.18, p.33-56, 2005

STEINSKOG, D.J., TJØSTHEIM, D.B.; KVAMSTØ, N.G. A cautionary note on the use of the Kolmogorov-Smirnov test for normality. Monthly Weather Review, v.135, p.1151-1157, 2007

TADESSE, T.; WILHITE, D.A.; MICHAEL J.; HAYES, M.J. Discovering associations between climatic and oceanic parameters to monitor drought in Nebraska using data-mining techniques. Journal of Climate, v.18, p.1541-1550, 2005.

TORRENCE, C.; COMPO, G.P. A practical guide to wavelet analysis. Bulletin of American Meteorological Society, v.79, p.61-78. 1998.
VLČEK, O.; HUTH R. Is daily precipitation Gamma-distributed? Adverse effects of an incorrect application of the KolmogorovSmirnov test. Atmospheric Research, v.93, p.759-766, 2009.

WILHITE, D.A. Drought as a natural hazard: Conceptions and definitions. In: WILHITE, D.A. Drought: A global assessment. Routledge, 2000. p.111-120.

WILKS, D.S. Statistical methods in the atmospheric sciences. 2.ed. San Diego: Academic Press, 2006. 629p.

WORD METEOROLOGICAL ORGANIZATION. Drought and agriculture. Geneva: WMO, 1975. 127p.

WU, H.; HAYES, M.J.; WILHITE, D.A.; SVOBODA, M.D. The effect of the length of record on the Standardized Precipitation Index calculation. International Journal of Climatology, v.25, p. 505-520, 2005.

WU, H.; SVOBODA, M.D.; HAYES, M.J.; WILHITE, D.A.; WEN, F. Appropriate application of the Standardized Precipitation Index in arid locations and dry seasons. International Journal of Climatology, v.27, p.65-79, 2007.

ZHAI, J.; SU, B.; KRYSANOVA, V.; TOBIAS, VETTER, T.; GAO, C.; JIANG, T. Spatial variation and trends in PDSI and SPI indices and their relation to streamflow in ten large regions of China. Journal of Climate, v.23, p.649-663, 2010.

ZHANG, Q.; XU, C.; ZHANG, Z. Observed changes of drought/ wetness episodes in the Pearl River basin, China, using the standardized precipitation index and aridity index. Theoretical and Applied Climatology, v.98, p.89-99, 2009. 